\title{
Hydrogen Cyanamide on Citrus: Preliminary Data on Phytotoxicity and Influence on Flush in Potted and Field Trees
}

\author{
Ed Stover ${ }^{1,4}$, Youjian Lin ${ }^{2}$, Xiaoe Yang ${ }^{2}$, and Tripti Vashisth ${ }^{3}$
}

ADDITIONAL INDEX WORDs. flowering, flush, fruit set, phytotoxicity, postbloom fruit drop

SUMMARY. Bloom in individual citrus (Citrus) trees often continues for more than 1 month in south Florida, with even greater bloom duration within most orchard blocks because of variation in bloom timing between trees. Prolonged bloom contributes to variable fruit maturity as harvest approaches and increases severity of postbloom fruit drop (PFD) disease (caused by Colletotrichum acutatum). Hydrogen cyanamide (cyanamide) has been effective in accelerating bloom in various deciduous fruits, and its potential use in citrus was investigated in this preliminary study. Cyanamide was applied at a range of concentrations, from $0 \%$ to $1.0 \%$ a.i., to potted trees of six citrus types reflecting fairly broad diversity in commercial citrus that was readily available as seed [alemow (Citrus macrophylla), 'Duncan' grapefruit (Citrus paradisi), sour orange (Citrus aurantium), 'Smooth Flat Seville' sour orange hybrid (C. aurantium hybrid), 'Swingle' citrumelo (C. paradisi $\times$ Poncirus trifoliata), and 'Sun Chu Sha' mandarin (Citrus reticulata)] in Dec. 1999 while trees were quiescent. Phytotoxicity increased with cyanamide rate, with some damage at $\mathbf{0 . 1 2 5 \%}$ cyanamide on most tested plants, and large variation among citrus types. All cyanamide rates hastened flushing. Airblast application of cyanamide $(0,0.025 \%, 0.05 \%$, and $0.10 \%)$ was made to mature trees of 'Valencia' and 'Navel' sweet orange (Citrus sinensis) in Ft. Pierce, FL, on 27 Jan. 2000. On 15 Feb. and 28 Feb. additional trees received cyanamide at $0.05 \%$. There was considerable defoliation, which increased linearly with cyanamide rate. Flushing and flowering were unaffected by cyanamide compared with controls except in February where cyanamide applied at $\mathbf{0 . 0 5 \%}$ increased flowers per tree in 'Valencia' sweet orange, and in contrast, $0.1 \%$ cyanamide on 27 Jan. reduced 'Navel' sweet orange flowering. Cyanamide application to 'Valencia' sweet orange on $28 \mathrm{Feb}$., after initial flowering but 16 days before peak bloom, significantly reduced yield per tree but there were no other effects on cropping. In these trials, cyanamide was not an effective agent for hastening bloom in south Florida citrus with applications late January through February. Further work is needed to determine whether December applications of cyanamide to trees in the field may be more effective in concentrating subsequent flush and bloom.

$\mathrm{H}$ ydrogen cyanamide (cyanamide) has been used as a dormancy-breaking and bloomhastening agent of deciduous fruit trees

\footnotetext{
This research was originally presented at the 2016 annual meeting of the Florida State Horticultural Society. Mention of trade names or commercial products is solely for the purpose of providing specific information and does not imply recommendation or endorsement by the US Department of Agriculture. USDA is an equal opportunity provider and employer.

${ }^{1}$ U.S. Horticultural Research Laboratory, U.S. Department of Agriculture, Agricultural Research Service, 2001 South Rock Road, Fort Pierce, FL 34945

${ }^{2}$ University of Florida, Indian River Research and Education Center, 2199 South Rock Road, Fort Pierce, FL 34945

${ }^{3}$ University of Florida, Citrus Research and Education Center, 700 Experiment Station Road, Lake Alfred, FL 33850

${ }^{4}$ Corresponding author. E-mail: ed.stover@ars.usda. gov
}

doi: 10.21273/HORTTECH03542-16 for many years (Carreno et al., 1999; Diaz et al., 1987; Dozier et al., 1990; Subhadrabandhu, 1995). Induction of uniform and earlier budbreak with cyanamide is reported to improve management and production of several deciduous crops in several tropical and subtropical areas worldwide (Aksoy et al., 1995; Buitrago et al., 1992; Carreno et al., 1999; Dozier et al., 1990; George and Nissen, 1993; Inglese et al., 1998; Jackson and Bepete, 1995; Lloyd and Firth, 1993; Or et al., 1999; Pontikis,
1989; Schuck and Petri, 1995; Snir and Erez, 1988; Tanino et al., 1989; Wood, 1993). In some regions, cyanamide use is a component of routine commercial production for several crops [e.g., apple (Malus $\times$ domestica), blueberry (Vaccinium corymbosum and hybrids), grape (Vitis vinifera), kiwifruit (Actinidia deliciosa), and peach (Prunus persica)].

Individual citrus trees in south Florida sometimes bloom for more than 1 month (E. Stover, unpublished data). Even greater bloom duration occurs within most orchard blocks because of variation in bloom timing between trees. Such prolonged bloom contributes to variable fruit maturity and increases severity of floral fungal diseases. PFD is a serious floral fungal disease caused by $C$. acutatum. This pathogen is stimulated to grow and produce spores by flower exudates; therefore, off-season or prolonged bloom period provides greater opportunity for inoculum development and makes disease control more difficult (Dewdney and Graham, 2016). PFD results in young fruit abscission and sometimes causes severe yield losses (Peres et al., 2002). Epidemic huanglongbing [HLB (associated with the bacterium Candidatus Liberibacter asiaticus)] in Florida causes the trees to be under chronic stress and results in multiple bloom periods and off-season bloom throughout the year (Dewdney and Graham, 2016), which exacerbates severity of PFD. Ability to shorten bloom duration and hasten bloom appears to offer several advantages to Florida citrus producers.

Cyanamide is primarily used on dormant deciduous species, and considerable leaf drop can result in citrus even when cyanamide drifts from adjacent vineyards (Ali and Lovatt, 2001). There is one report that cyanamide advances budbreak in mango [Mangifera indica (Notodimedjo, 1995)], which like citrus, is an evergreen subtropical fruit species. The objectives of this study were to assess

\begin{tabular}{llll}
\hline $\begin{array}{l}\text { Units } \\
\begin{array}{l}\text { To convert U.S. to SI, } \\
\text { multiply by }\end{array}\end{array}$ & U.S. unit & SI unit & $\begin{array}{l}\text { To convert SI to U.S., } \\
\text { multiply by }\end{array}$ \\
\hline 9.3540 & gal/acre & $\mathrm{L} \cdot \mathrm{ha}^{-1}$ & 0.1069 \\
2.54 & inch(es) & $\mathrm{cm}$ & 0.3937 \\
0.4536 & $\mathrm{lb}$ & $\mathrm{kg}$ & 2.2046 \\
28.3495 & $\mathrm{oz}$ & $\mathrm{g}$ & 0.0353
\end{tabular}

Hortednology $\cdot$ Decentoer $201626(6)$ 
phytotoxicity at a range of cyanamide concentrations and determine the potential benefit of using cyanamide to hasten flowering and reduce bloom duration of citrus in south Florida. This work was discontinued due to a change in program direction, but may now have current relevance due to problems associated with HLB and PFD. We find no published data on cyanamide in citrus and therefore submit this information as preliminary data.

Table 1. Phytotoxicity of hydrogen cyanamide applied to drip at different concentrations. Plants were small potted citrus trees maintained in a screenhouse and were quiescent on 23 Dec. 1999 when treatments were applied.

\begin{tabular}{|c|c|c|c|c|c|c|}
\hline \multirow{2}{*}{ Concn (\%) } & \multirow[b]{2}{*}{ Citrus tested } & \multicolumn{2}{|c|}{ Leaf injury score $(0-5 \text { scale })^{\mathrm{z}}$} & \multirow{2}{*}{$\frac{\text { Defoliation }(\%)^{y}}{\text { Day } 20}$} & \multicolumn{2}{|c|}{ Dieback of stems (\%) } \\
\hline & & Day 5 & Day 20 & & Day 5 & Day 20 \\
\hline \multirow[t]{5}{*}{ Control } & 'Swingle' citrumelo & 0.0 & 0.0 & 1.2 & 0.0 & 0.0 \\
\hline & Alemow & 0.0 & 0.0 & 1.8 & 0.0 & 0.0 \\
\hline & Sour orange & 0.0 & 0.0 & 1.2 & 0.0 & 0.0 \\
\hline & 'Smooth Flat Seville' sour orange & 0.0 & 0.0 & 1.3 & 0.0 & 0.0 \\
\hline & 'Sun Chu Sha' mandarin & 0.0 & 0.0 & 1.2 & 0.0 & 0.0 \\
\hline & Alemow & 4.0 & 4.8 & 96.7 & 100 & 73.3 \\
\hline & Sour orange & 0.7 & 1.2 & 3.3 & 0.0 & 16.7 \\
\hline & 'Smooth Flat Seville' sour orange & 0.7 & 0.7 & 6.7 & 0.0 & 0.0 \\
\hline & 'Sun Chu Sha' mandarin & 0.3 & 0.4 & 6.7 & 0.0 & 0.0 \\
\hline & 'Duncan' grapefruit & 0.7 & 1.8 & 51.7 & 0.0 & 0.0 \\
\hline \multirow{3}{*}{0.25} & 'Swingle' citrumelo & 2.0 & 3.0 & 90.0 & 0.0 & 75.0 \\
\hline & 'Sun Chu Sha' mandarin & 0.7 & 1.3 & 1.3 & 0.0 & 26.7 \\
\hline & 'Duncan' grapefruit & 1.8 & 3.2 & 96.3 & 0.0 & 33.3 \\
\hline \multirow[t]{6}{*}{0.50} & 'Swingle' citrumelo & 3.3 & 4.3 & 98.5 & 25.0 & 27.5 \\
\hline & Alemow & 5.0 & 5.0 & 100 & 100 & 100 \\
\hline & Sour orange & 3.2 & 3.5 & 50.0 & 80.0 & 96.6 \\
\hline & 'Smooth Flat Seville' sour orange & 1.3 & 4.0 & 84.3 & 63.3 & 33.3 \\
\hline & 'Sun Chu Sha' mandarin & 1.3 & 3.0 & 75.0 & 40.0 & 60.0 \\
\hline & 'Duncan' grapefruit & 0.3 & 4.0 & 66.7 & 90.0 & 66.7 \\
\hline \multirow[t]{4}{*}{1.00} & 'Swingle' citrumelo & 2.5 & 5.0 & 99.5 & 85.0 & 100 \\
\hline & Alemow & 5.0 & 5.0 & 100 & 100 & 100 \\
\hline & Sour orange & 2.0 & 5.0 & 100 & 43.3 & 60.0 \\
\hline & 'Smooth Flat Seville' sour orange & 2.3 & 5.0 & 100 & 43.3 & 56.7 \\
\hline
\end{tabular}

LSD = least significant difference.

${ }^{\mathrm{z}}$ Scores of $5,4,3,2,1$, and 0 refer to $100 \%, 80 \%, 60 \%, 30 \%, 15 \%$, and $<5 \%$ of total leaves that displayed necrosis or abscised from plants.

y Defoliation was surveyed on day 20 after the applications. The value represents the percentage of total leaves lost to defoliation.

Table 2. Effect of hydrogen cyanamide airblast applications on defoliation and blooming of mature trees of 'Valencia' and 'Navel' sweet orange.

\begin{tabular}{|c|c|c|c|c|c|}
\hline \multirow[b]{2}{*}{ Concn (\%) } & \multirow[b]{2}{*}{ Timing } & \multicolumn{2}{|c|}{ Defoliation (\%) } & \multicolumn{2}{|c|}{ Open flowers (no./tree) } \\
\hline & & $\begin{array}{c}\text { 'Valencia' sweet } \\
\text { orange }\end{array}$ & $\begin{array}{c}\text { 'Navel' sweet } \\
\text { orange }\end{array}$ & $\begin{array}{c}\text { 'Valencia' sweet } \\
\text { orange }\end{array}$ & $\begin{array}{c}\text { 'Navel' sweet } \\
\text { orange }\end{array}$ \\
\hline Control & & $11.2 c^{z}$ & $8.75 \mathrm{~b}$ & $330 \mathrm{ab}$ & $3852 \mathrm{a}$ \\
\hline 0.025 & 27 Jan. & $25.0 \mathrm{~b}$ & $13.75 \mathrm{~b}$ & $180 \mathrm{~b}$ & $2853 \mathrm{a}$ \\
\hline 0.05 & 27 Jan. & $33.2 \mathrm{~b}$ & $12.50 \mathrm{~b}$ & $321 \mathrm{ab}$ & $2831 \mathrm{ab}$ \\
\hline 0.10 & 27 Jan. & $53.7 \mathrm{a}$ & $28.75 \mathrm{a}$ & $170 \mathrm{~b}$ & $1215 \mathrm{~b}$ \\
\hline \multicolumn{6}{|l|}{ Contrast $P$ value } \\
\hline Cyanamide vs. control & & 0.0006 & 0.0015 & 0.6408 & 0.1628 \\
\hline Linear rate effect January only & & 0.0001 & 0.0004 & 0.6721 & 0.0221 \\
\hline
\end{tabular}

${ }^{\mathrm{z}}$ Within a column, means followed by the same letter are not significantly different at $P<0.05$ by Duncan's multiple range test. 


\section{Materials and methods}

SOURCE OF HYDROGEN CYANAMIDE. Cyanamide was applied as the product Dormex (SKW Trostberg, Trostberg, Germany) which is $50 \%$ a.i. No additional surfactant was used.

SCREENHOUSE EXPERIMENT. This experiment was conducted in a screenhouse in Ft. Pierce, FL. To determine an appropriate dosage of cyanamide for citrus and to get initial data on effects on shoot flushing, cyanamide was applied 23 Dec. 1999, at concentrations of $0.125 \%$, $0.25 \%, 0.5 \%$, and $1.0 \%$ a.i. to 2 -yearold potted plants of six different citrus types readily available as seed: alemow, 'Duncan' grapefruit, sour orange, 'Smooth Flat Seville' sour orange hybrid, 'Swingle' citrumelo, and 'Sun Chu Sha' mandarin. Most of these citrus types are not grown as scions except to produce seeds for rootstocks, but collectively these citrus types represent a broad crosssection of diversity from cultivated citrus. Off-type seedlings were not used. Cyanamide solution was applied to runoff using a backpack sprayer (Solo Inc., Newport News, VA). Three plants were used per cyanamide concentration for each citrus type. Shoot dieback, leaf necrosis, defoliation, and budbreak were surveyed $5,10,20,30$, and $40 \mathrm{~d}$ after the application. Leaf necrosis was scored as $5,4,3,2,1$, or 0 referring to $100 \%$, $80 \%, 60 \%, 30 \%, 15 \%$, or $<5 \%$, respectively, of total leaves that showed symptoms. The rates of defoliation and dieback of stems were recorded as the percentage of the total number of stems per plant that were affected. At 30 and $40 \mathrm{~d}$ after application, the percentage of terminals flushing and length of new flush were recorded, as percentage of main branches flushing at $30 \mathrm{~d}$ and percentage of individual shoots at $40 \mathrm{~d}$.

Field EXPERIMENT. All citrus types tested in the screenhouse, except alemow, have pedigrees derived solely from C. reticulata and Citrus maxima, like the sweet orange. Therefore, we felt it was reasonable to use these screenhouse data for guidance in conducting field experiments on sweet orange. Cyanamide concentrations of $0 \%, 0.025 \%, 0.05 \%$, and $0.10 \%$ were applied via airblast sprayer (Pak-Tank; Rears Manufacturing Co., Coburg, OR) at 125 gal/acre to mature trees of 'Navel' sweet orange on 'Carrizo' citrange

Table 3. Effect on flushing of hydrogen cyanamide applied to drip at different concentrations. Plants were small potted citrus trees maintained in a screenhouse and were quiescent on $23 \mathrm{Dec} .1999$ when treatments were applied.

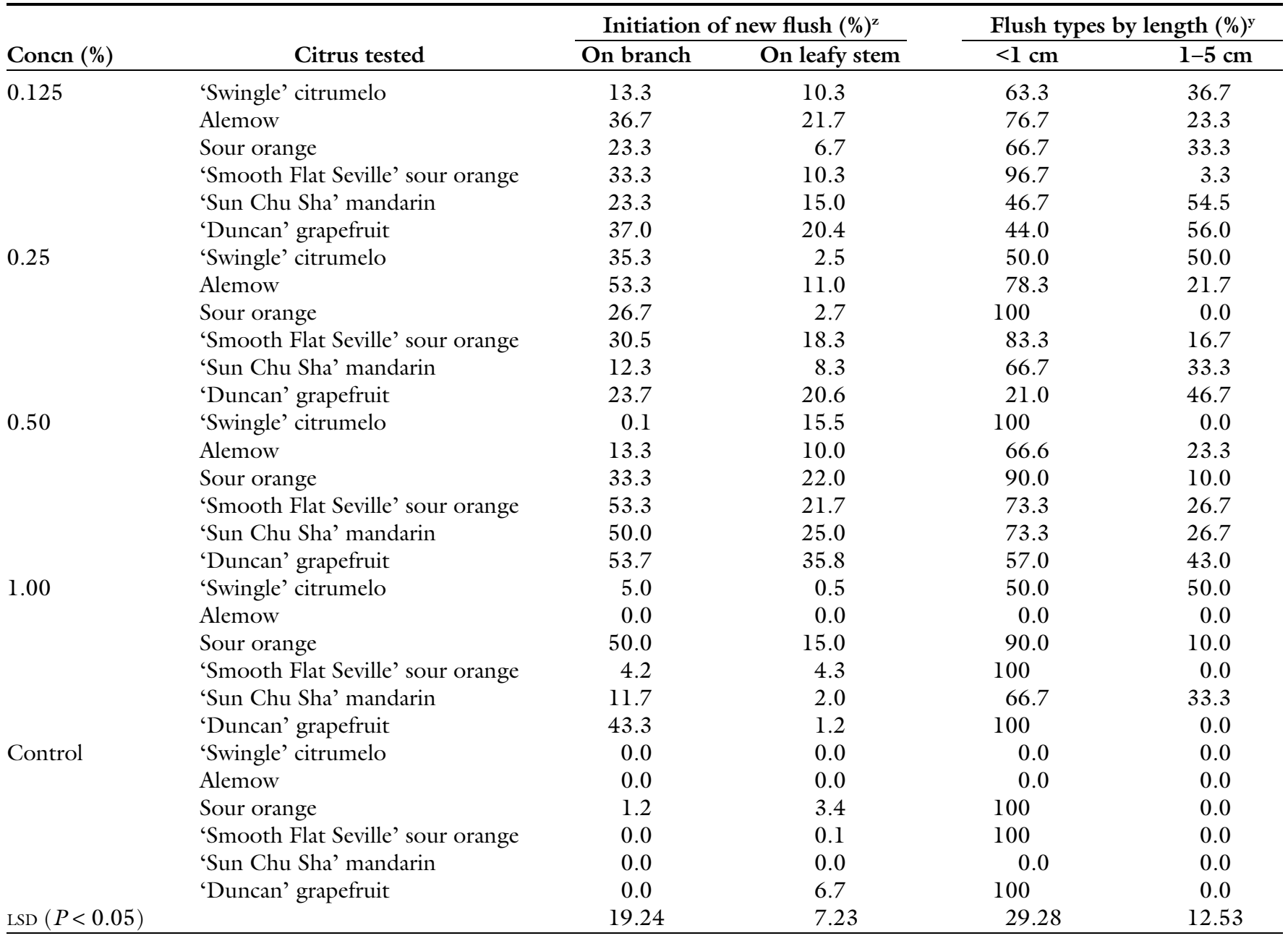

LSD $=$ least significant difference.

${ }^{\mathrm{z}}$ Initiation rates of new flushes on each branch were surveyed on day 30 after the applications. Initiation rates of new flushes across all leafy stems were surveyed on day 40 after the applications.

${ }^{\mathrm{y}}$ The length of new flushes was surveyed on day 40 after the applications; $1 \mathrm{~cm}=0.3937$ inch. 
(C. sinensis $\times P$. trifoliata) rootstock, and 'Valencia' sweet orange on rough lemon (Citrus jambhiri) rootstock at the Indian River Research and Education Center orchard in Fort Pierce, FL, on 27 Jan. 2000. On 15 Feb. and 28 Feb. additional trees randomized within the same orchard plot received cyanamide at $0.05 \%$, which was selected as a reasonable intermediate concentration based on the screenhouse experiment. Trials on each type of citrus were organized as randomized complete block experiments with four single-tree replications for each cyanamide treatment and blocking based on tree size and vigor. Following initial cyanamide application tree defoliation, flush development, and bloom were surveyed for each tree at a weekly interval for a period of 2 months. The defoliation was visually estimated as a percentage of the total leaves on the trees. The flush development was monitored in two ways, by visually estimating the percentage of dormant buds on leafy stems which sprouted and by measuring the length of typical flushes on each tree. Bloom was surveyed by counting open flowers on the same quadrant of each tree and multiplying by four. Yield, fruit number per tree, and fruit size were determined by harvesting all fruit from each experimental tree and measuring fruit size and number with a portable packing line.

Statistical analysis. Data were analyzed using the GLM procedure of SAS (version 9.4; SAS Institute, Cary, NC). For each data set, analyses included mean separations by least significant difference (LSD) and Duncan's multiple range test as well as contrast analyses to assess linearity of responses to cyanamide concentration. In the screenhouse experiments both main effects and interactions were assessed. Contrast analyses were also conducted on field experiments to compare groups of treatments to controls. For simplicity of presentation in large tables for these preliminary experiments, the screenhouse experiment data are presented using LSD for mean separations, and most interpretations are not different from those made looking only at interactions. Significance is indicated at $P<0.05$ unless otherwise indicated.

\section{Results and discussion}

EFFECTS OF HYDROGEN CYANAmide on foliage. Application of cyanamide to potted trees caused significant phytotoxic responses in all tested citrus types at concentrations as low as $0.25 \%$ (Table 1 ). Interactions were significant between main effect of citrus type and cyanamide concentration for almost every variable assessed, and across all citrus types (and most individual citrus types) phytotoxicity was significantly linearly related to cyanamide concentration. Types of citrus varied in their susceptibility to cyanamide damage, with a significant citrus type by cyanamide rate interaction showing especially great sensitivity in alemow. Cyanamide at $1 \%$, a typical rate for application to many crops such as almond (Prunus dulcis), apple, fig (Ficus carica), grapevine, peach, persimmon (Diospyrus kaki), and blueberry (Shulman et al., 1986; Williamson et al., 2002), caused essentially 100\% leaf burn and defoliation, and stem dieback on $56 \%$ to $100 \%$ of plants on all types of citrus tested by $20 \mathrm{~d}$ after application. $\mathrm{Cy}$ anamide at $0.125 \%$ produced rapid (within $5 \mathrm{~d}$ ) and extensive leaf injury on alemow, but more modest but significant damage occurred by $20 \mathrm{~d}$ after application on all other types of citrus except 'Sun Chu Sha' mandarin and 'Smooth Flat Seville' sour orange. However, only alemow and 'Duncan' grapefruit displayed significant defoliation and only alemow displayed significant stem dieback at $0.125 \%$ cyanamide.

Field experiment results (Table 2 ) showed that applications of cyanamide at concentrations ranging from $0.025 \%$ to $0.1 \%$ caused acceptable defoliation of trees of 'Navel' sweet orange ( $13.75 \%$ to $30 \%$ of canopy) and 'Valencia' sweet orange $(22.5 \%$ to $53.7 \%$ of canopy) compared with the nontreated controls. However, the defoliation rates caused by $0.1 \%$ in the field test were similar to (in 'Duncan' grapefruit which has sweet orange as a parent) or higher than that caused by $0.125 \%$ cyanamide in the screenhouse test for most types of citrus.
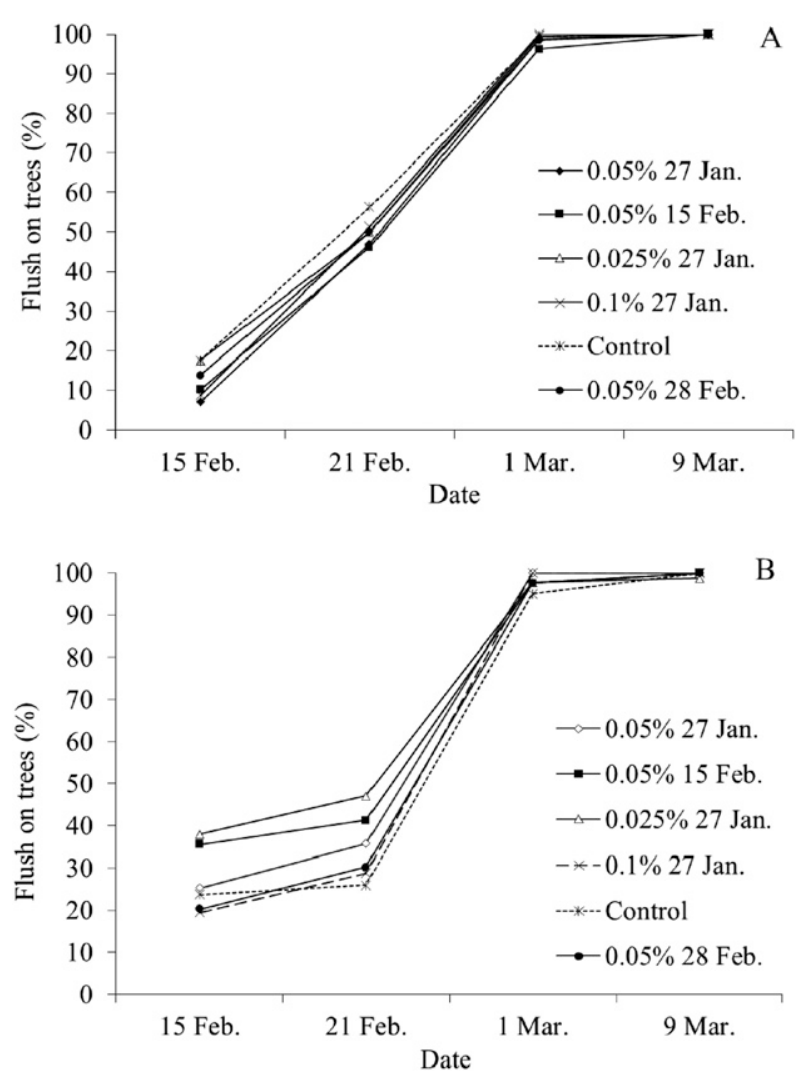

Fig. 1. Effect of hydrogen cyanamide applications on the spring flush development of (A) 'Navel' and (B) 'Valencia' sweet orange. No effects were significant at $P<$ 0.05 by Duncan's multiple range test. 
EFFECT OF HYDROGEN CYANAMIDE ON INITIATION AND GROWTH OF NEW FLUSH OF CITRUS. The results from the screenhouse test
(Table 3 ) showed that applications of cyanamide at concentrations ranging from $0.125 \%$ to $0.5 \%$ to the plants of six citrus types tested under the
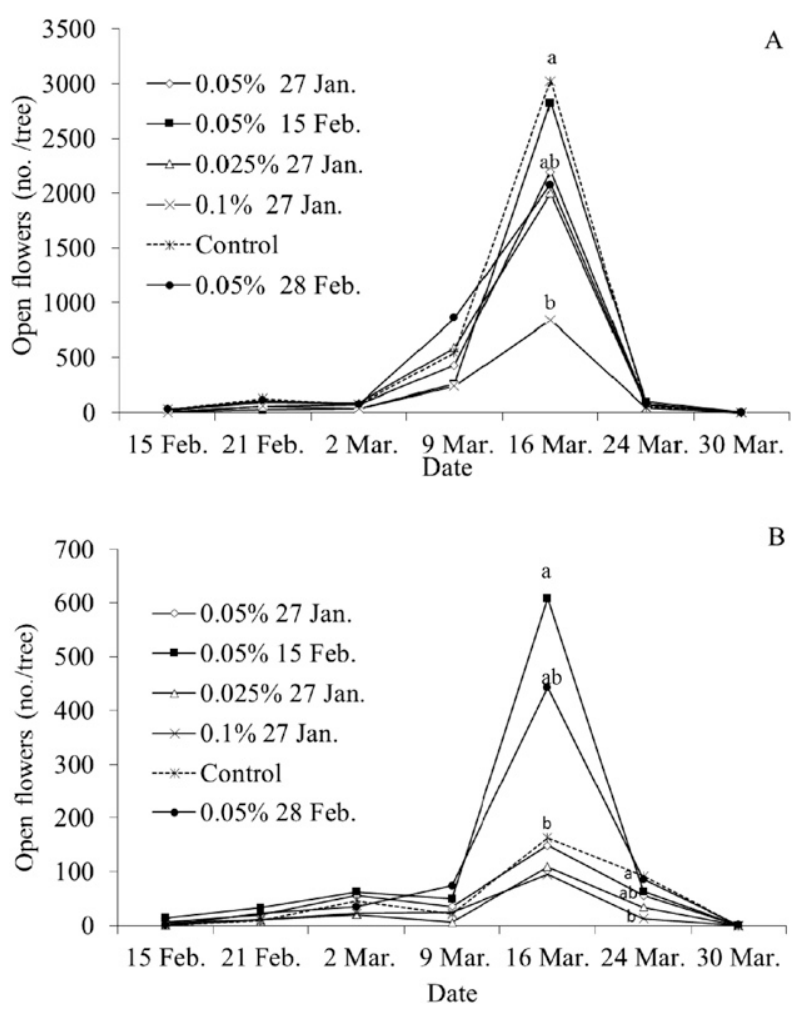

Fig. 2. Effect of hydrogen cyanamide applications on bloom of (A) 'Navel' and (B) 'Valencia' sweet orange. Open flowers per tree were counted in the same quadrant of each tree at each date and multiplied by four to estimate flowers per tree. Means at each date followed by the same letter were not significantly different at $P<0.05$ by Duncan's multiple range test. screenhouse conditions promoted the initiation and growth of new flushes in most citrus type by cyanamide concentrations, with $13.3 \%$ to $37 \%$ of branches showing flushing at $0.125 \%$ cyanamide. Interactions were significant between main effect of citrus type and cyanamide concentration for flushing, and across all citrus types (and most individual citrus types) flushing was not significantly linearly related to cyanamide concentration, in part due to severe phytotoxicity at higher concentrations. However, the results (Fig. 1) from the field experiment showed that the applications of cyanamide at concentrations ranging from $0.0125 \%$ to $0.1 \%$, applied during 27 Jan. through 28 Feb. 2000, had no significant effect on the initiation and growth of new flushes of 'Valencia' and 'Navel' sweet orange.

EFFECT OF HYDROGEN CYANAMIDE ON BLOOM OF CITRUS. The results (Table 2 ) showed inconsistent effect of cyanamide applications on total number of flowers. For applications on 27 Jan., 'Navel' sweet orange showed a significant linear effect of cyanamide concentration on reducing flower numbers. Only the $0.1 \%$ cyanamide rate (applied only on 27 Jan.) consistently reduced number of total flowers, which was significantly lower than $0.05 \%$

Table 4. Effect of hydrogen cyanamide on fruit set, fruit weight and yield of 'Valencia' and 'Navel' sweet orange in 2000.

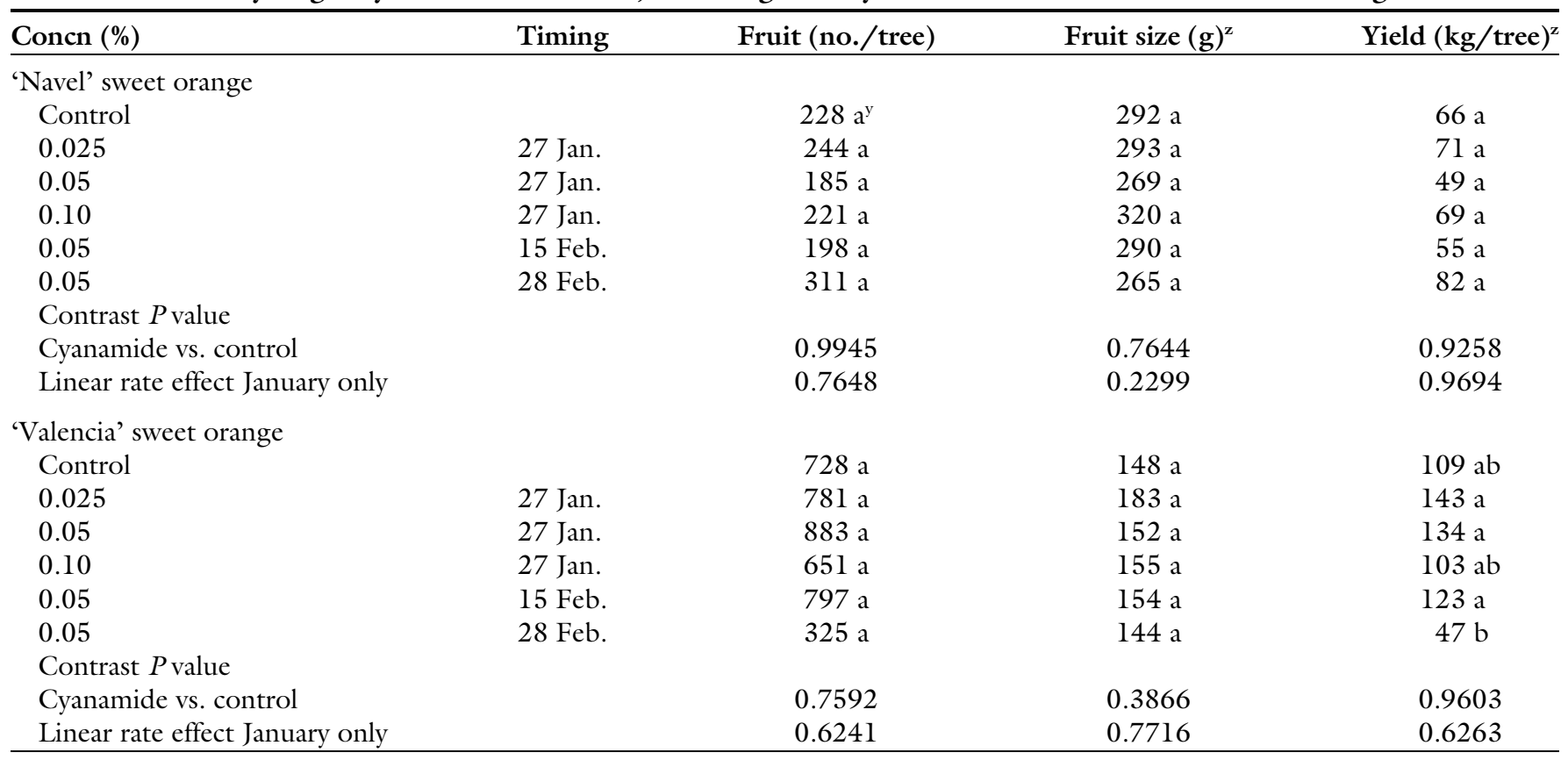

${ }_{\mathrm{z}} \mathrm{l} \mathrm{g}=0.0353 \mathrm{oz} ; \mathrm{l} \mathrm{kg}=2.2046 \mathrm{lb}$.

${ }^{\mathrm{y}}$ Within a column for each cultivar, means followed by the same letter are not significantly different at $P<0.05$ by Duncan's multiple range test. 
cyanamide applied 15 Feb. in 'Valencia' sweet orange and was significantly lower than the nontreated control and $0.025 \%$ cyanamide 27 Jan. in 'Navel' sweet orange. Duration of bloom and time of peak bloom of cyanamide-treated 'Valencia' sweet orange and 'Navel' sweet orange was not different from that of nontreated controls (Fig. 2).

EFFECT OF HYDROGEN CYANAMIDE ON CROPPING. The results (Table 4) showed that there were no significant differences in fruit set, fruit size, and yield of 'Valencia' and 'Navel' sweet orange between the trees treated with cyanamide and the nontreated control trees. We must note that variability between trees was high and compromised ability to distinguish treatment effects. 'Valencia' sweet orange trees treated with cyanamide at $0.05 \%$ on Feb. 28 had significantly lower yield than trees receiving several other cyanamide treatments, but was not different from the controls. The large differences required to reach statistical significance underscore the need for more replicates and more uniform trees.

Preliminary conclusions. Hydrogen cyanamide at $0.125 \%$ provided hastened flushing in five types of potted citrus trees treated on 23 Dec. 1999. At this concentration, acceptable levels of defoliation and other phytotoxicity were observed in most citrus types. Mature trees of 'Valencia' and 'Navel' sweet orange treated in late-Jan. to mid-Feb. 2000 showed somewhat excessive defoliation at $0.1 \%$ hydrogen cyanamide in 'Valencia' sweet orange and $0.05 \%$ provided $12.5 \%$ to $33.2 \%$ defoliation across both sweet orange cultivars. No acceleration of bloom or flush was observed, and we hypothesize that a late December application may hasten flushing and bloom.

Future Directions. These experiments were conducted before HLB become endemic in Florida. HLB-affected trees suffer from callose plugged phloem, loss of root system, altered mineral nutrition, phytohormone imbalance, and disruption of carbohydrate translocation that leads to arrested plant and fruit growth, and decline in production (Bové, 2006; Halbert and Manjunath, 2004; Rosales and Burns, 2011). We hypothesize that cyanamide- enhanced flushing in the fall may result in reduced phloem plugging in HLB-affected citrus. This is founded on possible common physiology between metabolism/degradation of callose plugs as plants are forced out of dormancy (Rinne et al., 2011) and the callose plugging of phloem in HLB-affected citrus (Achor et al., 2010). Experiments have been initiated to test cyanamide and several other materials for this purpose.

\section{Literature cited}

Achor, D.S., E. Etxeberria, N. Wang, S.Y. Folimonova, K.R. Chung, and L.G. Albrigo. 2010. Citrus affected with huanglongbing disease. Plant Pathol. J. 9:56-64.

Aksoy, U., S. Kara, A. Misirli, H.Z. Can, and G. Seferoglu. 1995. Effect of potassium nitrate and hydrogen cyanamide on apricot. Acta Hort. 384:431-434.

Ali, A.G. and C.J. Lovatt. 2001. Hydrogen cyanamide causes ethylene production and leaf abscission of 'Eureka' lemon. HortScience 36:521-522.

Bové, J.M. 2006. Huanglongbing: A destructive, newly emerging, century-old disease of citrus. J. Plant Pathol. 88:7-37.

Buitrago, M., G. Fischer, and T. Campos. 1992. Effect of hydrogen cyanamide on japanese plums in the region of Nuevo Colon, Boyaca. Acta Hort. 310:99-103.

Carreno, J., S. Faraj, and A. Martinez. 1999. The effects of hydrogen cyanamide on budburst and fruit maturity of 'Thompson Seedless' grapevine. J. Hort. Sci. Biotechnol. 74:426-429.

Dewdney, M. and J. Graham. 2016. Foliar fungal disease management in 2016. Citrus Ind. 97:24-27.

Diaz, D.H., A. Alvarez, and J. Sandoval. 1987. Cultural and chemical practices to induce uniform bud break of peach and apple under warm climates in Mexico. Acta Hort. 199:129-136.

Dozier, W.A., Jr., A.A. Powell, A.W. Caylor, N.R. McDaniel, E.L. Carden, and J.A. McGuire. 1990. Hydrogen cyanamide induces budbreak of peaches and nectarines following inadequate chilling. HortScience 25:1573-1575.

George, A.P. and R.J. Nissen. 1993. Effects of growth regulants on defoliation, flowering, and fruit maturity of the low chill peach cultivar Flordaprince in subtropical Australia. Austral. J. Expt. Agr. 33:787-795.
Halbert, S. and K. Manjunath. 2004. Asian citrus psyllids (Sternorrhyncha: Psyllidae) and greening disease of citrus: A literature review and assessment of risk in Florida. Fla. Entomol. 87:330353.

Inglese, P., G. Gullo, and L.S. Pace. 1998. Effect of cyanamide on budbreak and cane fruitfulness for 'Hayward' kiwifruit in relation to cane length and time of application. N. Z. J. Crop Hort. Sci. 26:45-53.

Jackson, J.E. and M. Bepete. 1995. The effect of hydrogen cyanamide (Dormex) on flowering and cropping of different apple cultivars under tropical conditions of sub-optimal winter chilling. Sci. Hort. 60:293-304.

Lloyd, J. and D.J. Firth. 1993. Effect of hydrogen cyanamide and promalin on flowering, fruit set, and harvest time of 'Flordaprince' peach (Prunus persica (L.) Batsch) in subtropical Australia. J. Hort. Sci. 68:177-183.

Notodimedjo, S. 1995. Influence of growth regulators Dormex, Promalin, foliar fertilizer Algifert and release of honey bees on the development and production of mango in East Java. Agrivita 18:43-50.

Or, E., G. Nir, and I. Vilozny. 1999. Timing of hydrogen cyanamide application to grapevine buds. Vitis 38:1-6.

Peres, N.A.R., N.L. Souza, S.E. Zitko, and L.W. Timmer. 2002. Activity of benomyl for control of postbloom fruit drop of citrus caused by Colletotrichum acutatum. Plant Dis. 86:620-624.

Pontikis, C.A. 1989. Effects of hydrogen cyanamide on bloom advancement in female pistachio (Pistacia vera L.). Fruit Var. J. 43:125-128.

Rinne, P.L., A. Welling, J. Vahala, L. Ripel, R. Ruonala, J. Kangasjärvi, and C. van der Schoot. 2011. Chilling of dormant buds hyperinduces FLOWERING LOCUS $\mathrm{T}$ and recruits GA-inducible 1 , 3 -beta-glucanases to reopen signal conduits and release dormancy in Populus. Plant Cell 23:130-146.

Rosales, R. and J.K. Burns. 2011. Phytohormone changes and carbohydrate status in sweet orange fruit from Huanglongbinginfected trees. J. Plant Growth Regulat. 30:312-321.

Schuck, E. and J.L. Petri. 1995. The effect of concentrations and application of hydrogen cyanamide on kiwifruit dormancy breaking. Acta Hort. 395: 177-184.

Shulman, Y., G. Nir, and S. Lavee. 1986. Oxidative processes in bud dormancy and 
the use of hydrogen cyanamide in breaking dormancy. Acta Hort. 179:141-148.

Snir, I. and A. Erez. 1988. Bloom advancement in sweet cherry by hydrogen cyanamide. Fruit Var. J. 42:120-121.

Subhadrabandhu, S. 1995. Induction of budbreak in apple trees that received insufficient chilling by hydrogen cyanamide. Acta Hort. 409:171-178.
Tanino, K.K., L.H. Fuchigami, T.H.H. Chen, L.V. Gusta, and C.J. Weiser. 1989. Dormancy-breaking agents on acclimation and deacclimation of dogwood. HortScience 24:353-354.

Williamson, J.G., G. Krewer, B.E. Maust, and E.P. Miller. 2002. Hydrogen cyanamide accelerates vegetative budbreak and shortens fruit development period of blueberry. HortScience 37:539-542.

Wood, B.W. 1993. Hydrogen cyanamide advances pecan budbreak and harvesting. J. Amer. Soc. Hort. Sci. 118: 690-693. 